\title{
KURUMSAL FİRMALAR İÇİN BİR FİNANSAL PERFORMANS KARŞILAŞTIRMA MODELİNİN GELİŞTİRİLMESİ
}

\author{
Yusuf Tansel İÇ, Muhteşem TEKİN, Fazıl Ziya PAMUKOĞLU, S. Erdinç YILDIRIM \\ Endüstri Mühendisliği Bölümü, Mühendislik Fakültesi, Başkent Üniversitesi, Bağlıca, 06810 Etimesgut/ Ankara. \\ vtansel@baskent.edu.tr; mehti05@hotmail.com;fazilziya@yahoo.com.tr;erdyldrm@gmail.com
}

(Geliş/Received: 13.03.2014; Kabul/Accepted: 16.09.2014)

ÖZET

Bu çalışmada Türkiye ekonomisindeki 24 sektördeki kurumsal firmaların sıralanmasına yönelik bir finansal performans değerlendirme modeli geliştirilmiş̧ir.Geliştirilen model finansal oranlar ve İdeal Çözümlere Yakınlık Yoluyla Tercihlerin Siralanması Tekniği (Technique for Order Preference by Similiarity to Ideal SolutionTOPSIS) yöntemi üzerine kurulmuştur.Model, aynı sektöre aitkurumsal firmaların rakiplerine göre derecelendirme puanlarını sunmaktadır. Geliştirilen model Visual Basic programıyla kodlanmış ve gerçek hayat çalışmalarıyla test edilmiştir. TOPSIS, Çok Kriterli Eniyileme ve Uzlaşık Çözüm (Vise Kriterijumska Optimizacija I Kompromisno Resenje-VIKOR), Gri İlişkisel Analiz (Grey Relational Grade-GRA) ve Oran Analizi Temelli Çok Amaçlı Eniyileme (Multi-Objective Optimization on the basis of Ratio Analysis-MOORA) yöntemlerinden elde edilen finansal performans değerlendirme sıralamaları Spearman'ın Sıra İlişkisi Testi kullanılarak karşılaş̧ırılmıştır. Test sonuçlarına göre finansal performans değerlendirme modeli için en uygun sıralama yönteminin TOPSIS yöntemi olduğu bulunmuştur. Makalede modelin çalışmasını gösteren bir uygulamaya da ayrıca yer verilmiştir.

Anahtar Kelimeler: Finansal analiz, finansal oran analizi, çok kriterli karar verme (ÇKKV), TOPSIS, VIKOR, GRA, MOORA.

\section{DEVELOPMENT OF A FINANCIAL PERFORMANCE BENCHMARKING MODEL FOR CORPORATE FIRMS}

\begin{abstract}
In this study, we developed a financial performance evaluation model to rank the corporate firms of 24 sectors in the Turkish economy.The developed model is based on the financial ratiosand Technique for Order Preference by Similiarity to Ideal Solution (TOPSIS)approach. This model of ferscorporate firm's rating scores with respect to its competitors belonging to the same industry. The developed model is coded in Visual Basic and tested with real case studies. Financial performance evaluation rankings obtained from TOPSIS, Vise Kriterijumska Optimizacija I Kompromisno Resenje (VIKOR), Grey Relational Grade (GRA), and Multi-Objective Optimization on thebasis of Ratio Analysis (MOORA) methods were compared by using Spearman's rank correlation test. Based on the test results, it was found that the TOPSIS method is the most appropriate method for the evaluation of financial performance. An application is also provided in the paper for illustrative purposes.
\end{abstract}

Keywords: Financial analysis, financial ratio analysis, multi criteria decision making (MCDM), TOPSíS, VIKOR, GRA, MOORA.

\section{GÍRIŞ̧ (INTRODUCTION)}

Finansal analiz, bilanço ve gelir tablosu gibi finansal tablolarda yer alan hesap kalemleri arasındaki ilişkilerin kurulmasını ve yorumlanmasını kapsayan bir süreçtir.Finansal analiz, bizzat firmaların kendileri tarafından yapılabileceği gibi, firmalara kredi veren kurumlar (bankalar ve diğer finans kuruluşları) veya yatırımcılar tarafindan da yapılabilir.

Finansal analiz yapılarak bir firmaya ilişkin $i$ ) firmanın likidite durumu, ii) firmanın karlılık durumu, 
iii) firmanın sermaye yapısı, $i v$ ) firmanın aktiflerinin kullanım durumu gibi konularda bilgi sahibi olunabilir.

Finansal analizde kullanılan finansal oran, finansal tablolarda yer alan çeşitli kalemler arasındaki basit matematiksel ilişkileri gösterir [1]. Sağlıklı bir finansal analiz için onlarca elde edilebilecek olan finansal oranlar arasından gerçekten gerekli olan oranlar hesaplanarak yorumlanmalı ve sektör ortalamaları ile karşılaştırılmalıdır.

Finansal oranlar temel olarak dört grupta sınıflandırılmaktadır. Birinci grupta likidite oranları yer almaktadır. Likidite, bir varlığın hızlı bir şekilde nakde dönüşebilme kabiliyetidir [1]. İkinci grupta ise finansal yap1 oranları yer almaktadır. Finansal yapı oranları, firmaların faaliyetlerinin hangi ölçüde yabancı kaynakla (borçlanmayla) finanse edildiğini ve yabancı kaynak finansmanının firma için ne düzeyde faydalı olduğunu değerlendirmeye yarayan oranlardır. Üçüncü grupta faaliyet oranları yer alır. Faaliyet oranları, firmaların varlıklarının ne ölçüde etkin kullandıklarını gösteren oranlardır. Dördüncü ve son grupta yer alan karlılık oranları ise işletmelerin faaliyetleri sonucunda elde ettikleri başarıyı (kar etme düzeyini) ölçmeye yarayan oranlardır.

Finansal analiz geniş kapsamlı bir bilimsel disiplin olup, muhasebe prensiplerine hâkimiyetle birlikte, muhasebe kalemlerinin finansal tablolara yansımalarının yorumlanması, birbiriyle ilişkilerinin analizi gibi uzmanlık ve uzun yıllar tecrübeyi gerektiren bir alandır. Başarılı bir finansal analiz, sağlıklı ve muhasebe sistemi kurallarına uygun olarak doğru prensiplerle oluşturulmuş finansal tablolara bağlıdır. Muhasebe standartları ve finansal tabloların oluşturulması bu makale çalışması kapsamının dışında olup, ilgilenen okurlar detaylı bilgiler için [1] nolu kaynağa başvurabilirler.

Bu çalışmada Borsa İstanbul'da (BİST) işlem gören firmaların finansal oran verileri ve TOPSIS yöntemi kullanılarak bilgisayar destekli bir finansal performans değerlendirme sistemi oluşturulmuştur. Olușturulan sistemin veri tabanında BIST'te ișlem gören firmalar 24 farklı sektör grubunda sınıflandırarak her bir firmanın kendi sektörü içerisindeki firmalarla finansal performansının karşılaştırılması hedeflenmiştir. Her bir sektör grubunda faaliyet gösteren firmaların sektörden kaynaklanan üretim, pazarlama, yurtiçi/dışı alış/satış koşulları, ulusal/uluslararası rekabet koşulları gibi etkenler nedeniyle; "stoklar", "maddi duran varlıklar", "ticari alacaklar/borçlar", "yurtdışı satıșlar", "banka kredileri", "satılan malın maliyeti" ve "ödenecek faiz" gibi finansal kalemleri bir sektördeki firmadan diğerine farklılıklar taşıyabilmektedir. Dolayısıyla farklı sektörlerdeki firmaları bir arada değerlendirmek (örneğin imalat firmaları, enerji sektöründeki firmalar ve ulaştırma sektöründeki firmaları bir arada değerlendirmek) elde edilecek finansal performans sıralaması açısından uygun bir yaklaşım olmamaktadır.

Kullanıcı sektör seçimi yaptıktan sonra, sektördeki yer alan firmaları finansal performanslarına göre siralayabilmektedir. Diğer taraftan esnek yapıda tasarlanan modele ilgili sektörlerde faaliyet gösteren yeni firma verilerinin eklenmesi ve böylece sektörel bazda firma sayısının artırılma imkânı da sağlanmıştır. Literatürde hedef alınan belli sektörlerde faaliyet gösteren (örneğin tekstil, çimento, otomotiv v.b.) firmaların finansal performans ölçüm/derecelendirme çalışmaları mevcuttur. Bu çalışmada ise Türkiye'de faaliyet gösteren ve verilerine ulaşım imkânı bulunan tüm sektörlerdeki firmaların kendi sektörlerindeki finansal performans durumlarının belirlenebileceği bir model tasarlanmaya çalışılmıştır. Model, firma finansal performans sıralaması çalışmalarına ihtiyaç duyan bankalar, finansal kuruluşlar, yatırımcılar ve rekabet imkânlarını değerlendirmek veya diğer firmalarla kıyaslamak isteyen firmalar açısından kullanılabilir nitelikte tasarlanmıştır.

Makalede 2. Bölümde literatür taramasına yer verilmekte, 3. Bölümde geliştirilen finansal performans ölçüm modeli tanıtılmakta, 4. Bölümde modelin uygulama örneklerine yer verilmekte, 5 . ve 6 . Bölümlerde ise çalışma kapsamında ulaşılan sonuçlar aktarılmaktadır.

\section{LITERATÜR TARAMASI (LITERATURE SURVEY)}

Literatürde finansal analizin objektif yöntemlerle gerçekleştirildiği ilk çalışmalar 1970'li yıllarda Altmanv. d. [2] tarafından gerçekleştirilmiştir. Altmanv. d., firmaların başarılarında ve finansal açıdan başarısız olarak iflas etmelerinde etkili olan finansal oranları analiz ederek, çok değişkenli diskriminant analizini kullanmak suretiyle "Z-Skor Modeli" olarak adlandirılan bir diskriminant fonksiyonu elde etmiştir. Firmanın ilgili finansal oran değerlerinin fonksiyonda yerine yazılmasıyla elde edilen Z-skor değeri, yine Altmanv. d. tarafindan geliştirilen bir ölçekle karşılaştırılarak firmanın gelecekteki başarısı hakkında bir değerlendirme yapılabilmektedir. Altman v. d.'nin çalışmasında kullanılan finansal oranların geçmiş yıl verilerine dayanması ve yıllar ilerledikçe modelin, yenilenmesi gereken geçmiş yıl finansal oran setleriyle güncellenmesi zorunluluğu ve her zaman sağlıklı veri setlerine ulaşılamaması gibi sorunlar nedeniyle yeni metodolojilere ihtiyaç doğmuştur. 1980'li yıllardan itibaren Çok Kriterli Karar Verme (ÇKKV) yöntemlerinin ortaya çıkması, bu çalışmaların kullanıldığı finansal performans ölçüm çalışmalarının yaygınlaşmasına yol açmıştır. İlk olarak geliştirilme 
ve yaygınlaşma sürecine paralel olarak, Analitik Hiyerarşi Prosesi (AHP) ve TOPSIS yöntemleriyle gerçekleştirilen çalışmaların ardından, daha sonraki yıllarda gelişen ve yaygınlaşan Analitik Ağ Süreci (ANP) [3,4], VIKOR [5], PROMETHEE [6,7], Veri Zarflama Analizi (VZA) [8],UTilités Additives DIScriminantes(UTADIS) [9], GRA [10]ve MOORA [11] gibi yöntemlerle çeşitli sektörlerde performans ölçüm çalışmaları ortaya konmuştur. $\mathrm{Bu}$ alandaki çalışmalarda temel hedef; daha hızlı, daha yalın ve gerçek hayattaki uzman görüşlerine daha yakın siralamayı verebilecek metodolojilerle yeni finansal performans ölçüm modellerinin ortaya konma çabasıdır. Son yıllarda ise finansal performans değerlendirme çalışmalarında uzman görüşlerine ihtiyac1 en az düzeye indirerek daha objektif modellerin ortaya konmasına yönelik çalışmalar gerçekleştirilmeye başlanmıştır. Bu tür çalışmalara örnek olarak Deney tasarımı ve TOPSIS yönteminin birleştirildiği ve kriter ağırlıklandırma sürecinde uzman görüşüne ihtiyacı en aza indirmeye çalışan İç [12] tarafından gerçekleştirilen çalışma örnek olarak verilebilir. $\mathrm{Bu}$ çalışmada finansal performans verilerinin alt ve üst sınırları kullanılarak $2^{\mathrm{k}}$ deney tasarımıyla (2: performans kriterinin-finansal oran- alt ve üst seviyesini, k: kriter sayısını ifade etmektedir) elde edilen deney seti karar matrisi olarak TOPSIS yöntemine aktarılmaktadır. Ardından kriterlere 1-10 arasında rastgele atanan ağırlıklar kullanılarak hesaplanan TOPSIS siralama puanlarına dayalı bir regresyon fonksiyonu elde edilmektedir. Elde edilen regresyon fonksiyonu kullanılarak da firmaların sıralama puanları hesaplanabilmektedir. Yöntemin literatürde geçmiş yıllarda gerçekleştirilen ÇKKV yöntemlerinin kullanıldığı finansal performans değerlendirme çalışmalarına uygulanması sonucunda, birbirine çok yakın sıralama sonuçlarının elde edilebildiği görülmüştür [12].

Literatür incelendiğinde finansal oranların kriter olarak kullanıldığı ve ÇKKV yöntemleri kullanılarak firmaların finansal performanslarına göre siralandığ çalışmalardan örneklere aşağıda yer verilmektedir:

İç ve Yurdakul [13] ve Yurdakul ve İç [14] tarafından gerçekleştirilen çalışmalarda AHP yöntemini kullanarak tekstil sektöründe faaliyet gösteren firmaların derecelendirildiği ve bankaların kredi derecelendirme faaliyetlerinde kullanılabilir nitelikte bir model sunulmuştur. Başka bir çalışmada Yurdakul ve İç [15] TOPSIS yönteminin kullanarak Türk otomotiv firmalarının finansal performanslarının derecelendirildiği bir çalışma gerçekleştirmişlerdir. Diğer bir çalışmada Ertuğrul ve Karakaşoğlu [16] Bulanık AHP- TOPSIS bütünleşik yöntemini kullanarak Türk çimento firmalarını finansal performanslarına göre sıralamışlardır. İç ve Yurdakul [17] Bulanık TOPSIS yönteminin kullanıldığı ve bankaların kredi talep eden firmaları hızlı bir şekilde değerlendirerek daha detaylı analize sevk edilip edilmemesi gerektiğinin tespitine yönelik bir karar destek sistemi geliştirmişlerdir. Seçme ve diğerleri [18] ise Bulanık AHP- TOPSIS bütünleşik yöntemini kullanarak Türkiye'nin beş büyük bankasının finansal başarılarına göre derecelendirildiği bir çalışma sunmuşlardır. Başka bir çalışmada BabicandPlazibat [19] AHP ve PROMETHEE yöntemlerini kullanarak kurumsal firmaları derecelendiren bir çalışma gerçekleştirmiştir. Mostafa [8] ise Arap Bankaları'nın finansal performanslarını VZA yöntemini kullanarak değerlendiren bir çalışma gerçekleştirmiştir. Deng ve diğerleri [20] kurumsal firmaların finansal performansların karşılaştırmalı analizinin yapıldığı ve TOPSIS yönteminin kullanıldığı bir çalışma sunmuşlardır. Moghimi ve Anvari [21] Bulanık AHPTOPSIS bütünleşik yöntemini kullanarak İran'da faaliyet gösteren çimento firmalarının finansal performanslarına göre derecelendirildiği bir çalışma gerçekleştirmiştir. Yalçın ve diğerleri [5] Bulanık AHP ile TOPSIS ve VIKOR yöntemlerini ayrı ayrı birleştirerek Türk gıda, kâğıt, kimya, metal, metal ve makine imalatı, metal dişı imalat ve tekstil sektörlerindeki firmaların finansal performanslarına göre sıralandığı ve ardından TOPSIS ve VIKOR yöntemi sıralama sonuçlarının kıyaslandığı bir çalışma gerçekleştirmişlerdir. Voulgaris ve diğerleri [9] UTADIS metodunu kullanarak Yunan Küçük ve Orta Boy İşletmeleri (KOBI) finansal performanslarına göre sıralayan bir çalışma sunmuşlardır. Bulgurcu [22] İstanbul Menkul Kıymetler Borsası'nda (İMKB-bugünkü adıyla Borsa İstanbul-BİST) faaliyet gösteren teknoloji şirketlerinden 13 adetini finansal performanslarına göre TOPSIS yöntemiyle derecelendiren bir çalışma sunmuştur. TOPSIS yöntemini kullanan diğer bir finansal performans değerlendirme çalışmasında Feng ve Wang [23] Tayvan havayolu şirketlerini derecelendirmiştir. Tayvan havayolu şirketlerinin derecelendirildiği benzer bir çalışmada ise Wang [24] finansal performans derecelendirme yöntemi olarak GRA ve Bulanık TOPSIS yöntemlerini birlikte kullanmıştır. Tung ve Lee [25] Tayvan'daki biyoteknoloji firmalarının finansal performans değerlendirmesinde GRA yöntemini kullanmışlardır. GRA yöntemiyle gerçekleştirilen diğer finansal performans değerlendirme çalışmalarında Lee ve diğerleri [26] Tayvan ve Kore gemicilik şirketlerini, Kung ve Wen [27], Tayvan'daki girişim sermayesi şirketlerini, Wang [10], Tayvan'daki konteynır taşıma hattı işletmelerini, Huang ve Chung [28] ise Çin kurumsal firmalarını derecelendiren çalışmalar gerçekleştirmişlerdir. Literatürde diğer ÇKKV yöntemlerine göre nispeten yeni bir yöntem olan MOORA yönteminin kullanıldığı Brauers [11] tarafından gerçekleştirilen çalışmada, liman inşaatı yüklenicisi firmaların projelerine ilişkin Net Bugünkü Değer (NBD), İç Verim Oranı (IRR), geri ödeme süresi gibi ekonomik göstergeler kriter olarak kullanılarak firmalar proje değerliliklerine göre sıralanmıştır. Yine Brauers ve diğerleri [29] 
tarafından gerçekleştirilen ve MOORA yönteminin uygulandığ 1 diğer bir çalışmada Litvanya'daki taahhüt firmalarının maliyet muhasebesine dayalı proje yönetim performanslarına göre derecelendirildiği bir çalışma gerçekleştirilmiştir. Literatürde taahhüt sektörü firmaları performans değerlendirme [29], imalat teknolojisi seçimi [30], malzeme seçimi [31] ve kaliteli ürün tasarımı [32] gibi farklı alanlarda kullanımı bulunan bu yeni yöntemin finansal oranlar kullanılarak firmaların performans siralamasının gerçekleştirildiği bir çalışmaya literatürde rastlanılmamıştır. MOORA yönteminin firma finansal performans derecelendirmede kullanılabilirliğine ilişkin uygulamaya çalışmamızda yer verilerek yöntemin diğer ÇKKV yöntemiyle karşılaştırılması da gerçekleştirilmiştir. Yönteme ilişkin değerlendirmeler Bölüm 5 'te verilmektedir.

Literatürdeki çalışmalar incelendiğinde ÇKKV yöntemlerinin uygulandığı finansal performans ölçüm çalışmalarında en fazla kullanılan yöntemin TOPSIS yöntemi olduğu görülmektedir. Bunun en önemli sebebi yöntemin kolay anlaşılır olması, basit matematiksel ilişkilere dayanması ve dolayısıyla uygulama kolaylığıdır. Diğer taraftan yöntemin yapısı gereği karar matrisinin oluşturulmasıyla işlem adımlarının başlamasının finansal performans ölçümünde getirdiği kolaylıklar da kullanım yaygınlığının bir diğer nedeni olarak gösterilebilir.

Karar matrisinin sonraki adımı verilerin normalizasyonu olduğundan, karar matrisinde hem oransal değerler (örneğin Net Kar/Öz Kaynak=5) hem de miktarsal değerler (örneğin Net işletme Sermayesi $=1$ Milyon TL) aynı matriste bulunabilmektedir. Böylece finansal analizde önemli olan kaynakların verimli kullanımına ilişkin "Net İşletme Sermayesinin Değeri" gibi faaliyet göstergeleri ile Net Kar/Öz Kaynak gibi performans göstergelerinin aynı anda değerlendirilme imkânını sağlanabilmektedir. Geliştirilen modele ilişkin detaylı bilgiler aşağıdaki bölümde açıklanmaktadır.

\section{FINANSAL DEĞERLENDİRME GELISTIRILMESİ (DEVELOPMENT OF THE FINANCIAL PERFORMANCE EVALUATION MODEL)}

$\mathrm{Bu}$ bölümde firmaların finansal performanslarının değerlendirilmesinde kullanılacak modelin geliştirilme adımlarından bahsedilmektedir. Çalışmada "kurumsal nitelikli firmalar" bir başka deyişle yıllık net satış tutarı 25 Milyon TL'nin üzerindeki büyük ölçekli firmalar değerlendirme kapsamında tutulmaktadır. Geliştirilen modelin kurumsal firmalara yönelik olmasının temel nedeni verilerine ulaşılabilen firmaların kurumsal nitelikli firmalar olmasından kaynaklanmaktadır. Model içeriğinde firmaların sektörel bazda finansal performans düzeyinin ölçümünde kullanılacak finansal oran verileri Kamuyu Aydınlatma Platformu (KAP-www.kap.gov.tr) [33] tarafindan yayınlanan firma bilanço-gelir tabloları kullanılarak oluşturulmuştur.

KAP'ta sektörel bazda gruplandırılmış olan firmaların bilanço ve gelir tabloları indirilmiş ve sektördeki her bir firmanın finansal oranı hesaplanmıştır. Firmalara ait finansal verilerin ve finansal oranların yer aldığ veri tabanı MS Excel'de oluşturulmuştur. Veri tabanında 24 adet sektör ve toplamda 198 adet firmanın finansal oran verileri bulunmaktadır. Çalışma kapsamında kullanılan finansal oranlar ve oranların hesaplanma formülleri aşağıdaki Çizelge 1 'de sunulmuştur.

Çalışmada kullanılan finansal oranlar belirlenirken her bir finansal oran grubunda literatürde ve finans sektörü uygulamalarında genel kabul görmüş olan temel finansal oranlar kullanılmıştır. Finansal oranların sayısının artırılması mümkün olmakla birlikte, artan finansal oran sayısı beraberinde finansal oranlar arasındaki bağımlılı̆̆ın da artmasına neden olacağından tercih edilmeyen bir durumdur.

Örneğin karlılık oranlarında finansal oranların hesaplanmasında "net satışlar"a göre oranlama işlemi gerçekleştirilmektedir. Eğer net satışlara oranlamanın kullanıldığı daha fazla sayıda finansal oran kullanılırsa her bir oranın sıralama sonuçları üzerindeki etkisi azalacaktır. Ayrıca benzer oranlarla elde edilecek aynı amaca hizmet eden birbirine yakın oran değerleriyle TOPSIS yönteminin gerçekleştirilmesi, sıralama sonuçlarını olumsuz etkileyebilecektir.

$\mathrm{Bu}$ nedenle çalışmada karlılık oranları ve finansal yapı oranlarıyla ilgili olarak finansal performansı tek başına yeterli bir şekilde gösterebilecek tarzdaki finansal oranlar kullanılmıştır. Diğer taftan faaliyet oranları açısından alacak devir hızı, borç devir hızı ve stok devir hızının her üçünün de değerlendirilmesi finansal analiz açısından gerekli bir durumdur. Firmanın borç devir hızı borçlarını yılda kaç kez ödemesi gerektiğinin bir ölçüsüyken, stok devir hızı stoklarını yılda kaç kez satışa çevirdiğini, alacak devir hızı ise alacaklarını yılda kaç kez tahsil ettiğinin bir göstergesidir.

Bir firma için borç devir hızının düşük değerde, alacak devir hızı ve stok devir hızının yüksek değere sahip olması arzulanır. Dolayısıyla bu üç faaliyet oranının da aynı model içerisinde değerlendirilmesi gerekmektedir.

Likidite oranları açısından ise firmanın stoklar dâhil nakde çevirebilme imkânı olan tüm dönen varlıklarının kısa vadeli yabancı kaynaklara oranını temsil eden cari oran, kısa sürede nakde çevrilme imkânı olan dönen varlıklarının kısa vadeli yabancı 
Çizelge 1. Finansal oranlar (Financial ratios)

\begin{tabular}{|c|c|c|}
\hline Finansal Oran Grupları & Oran & Açıklama \\
\hline \multirow{3}{*}{ Likidite Oranları } & Cari Oran & [Dönen Varlıklar/ Kısa Vadeli Yabancı Kaynaklar]*100 \\
\hline & Likidite Oranı & $\begin{array}{l}\text { [Dönen Varlıklar- (Stoklar +Verilen Avanslar+Peşin Ödenmiş } \\
\text { Giderler+Diğer Dönen Varlıklar) / Kısa Vadeli Yabancı } \\
\text { Kaynaklar]*100 }\end{array}$ \\
\hline & Net İşletme Sermayesi & Dönen Varlıklar - Kısa Vadeli Yabancı Kaynaklar \\
\hline \multirow{4}{*}{ Faaliyet oranları } & Alacak devir hızı & Net Satışlar / (Kısa+Uzun Vadeli Ticari Alacaklar) \\
\hline & Stok devir hızı & Satışların Maliyeti/ [(Cari Yıl Stoku+Önceki Yıl Stoku)/2] \\
\hline & Borç devir hızı & Net Satışlar/ (Kısa+Uzun Vadeli Ticari Borçlar) \\
\hline & Aktif devir hızı & Net Satışlar/Aktif Toplamı \\
\hline \multirow{3}{*}{ Karlılık Oranları } & $\begin{array}{l}\text { (Esas Faaliyet Karı / Net } \\
\text { Satışlar)*100 }\end{array}$ & Firmanın faaliyetleri sonucundaki karlılığını gösterir. \\
\hline & (Net Kar / Net Satışlar)*100 & Firmanın toplam faaliyetleri sonucundaki karlılığını gösterir \\
\hline & (Net Kar / Öz Kaynak)*100 & Özkaynak karlılığının göstergesidir \\
\hline \multirow[b]{2}{*}{ Finansal Yapı Oranları } & (Toplam Borç/Pasif Toplamı)*100 & $\begin{array}{l}\text { Firmanın faaliyetlerinin ne kadarını yabancı kaynakla (dışarıdan } \\
\text { borçlanarak) finanse ettiğini gösterir. }\end{array}$ \\
\hline & (Finansal Borçlar/Özkaynak)*100 & $\begin{array}{l}\text { Firmanın finansal borçlarının ne kadarını özkaynaklarıyla } \\
\text { karşıladığını gösterir. }\end{array}$ \\
\hline
\end{tabular}

kaynaklara oranlandığı likidite oranı ve firmanın işletme sermayesi değeri likidite oranlarını temsil eden finansal göstergeler olarak alınmıştır. $\mathrm{Bu}$ üç gösterge finansal analizde likiditenin ölçümünde kullanılan en temel oranlardır.

\subsection{Firma Derecelendirme (Firm Rating)}

Geliştirilen model sektörel bazda firmaların derecelendirilmesinde ÇKKV yöntemlerinden biri olan TOPSIS yöntemini kullanmaktadır. Modelde karar verici istediği bir sektördeki firmaları kendi aralarında finansal performanslarına göre derecelendirebildiği gibi, aynı sektördeki yeni firma/firmaların finansal oran verilerini değerlendirme yapılacak sektörün veri tabanına ekleyerek de sıralama işlemi gerçekleştirebilmektedir.

Model içerisinde kullanılan TOPSIS yönteminin uygulama adımları aşağıda belirtilmiştir $[12,15,16]$ :

\section{Adım 1: Karar matrisinin oluşturulması}

Yöntemin ilk adımı karar verici tarafindan karar matrisinin oluşturulmasıdır.

Karar matrisinde $m$ derecelendirilecek alternatif sayısını $(i=1, \ldots m$, firma sayısını), $n$ ise değerlendirme kriteri $(j=1, \ldots, n$, finansal oranlar $)$ sayısın $1, a_{\mathrm{ij}}$ ise finansal oran değerini ifade eder.

$$
A_{i j}=\left[\begin{array}{cccc}
a_{11} & a_{12} & \ldots & a_{1 n} \\
a_{21} & a_{22} & \ldots & a_{2 n} \\
\cdot & & & \cdot \\
\cdot & & & \cdot \\
\cdot & & & \cdot \\
a_{m 1} & a_{m 2} & \ldots & a_{m n}
\end{array}\right]
$$

Adım 2: Normalize karar matrisinin oluşturulması

Normalize karar matrisi, Adım 1'de oluşturulan $A$ matrisinin elemanları kullanılarak ve aşağıdaki formülden yararlanarak oluşturulur.

$$
r_{i j}=\frac{a_{i j}}{\sqrt{\sum_{k=1}^{m} a_{k j}^{2}}}
$$

$R$ normalize karar matrisi aşağıdaki gibi elde edilir:

$$
R_{i j}=\left[\begin{array}{cccc}
r_{11} & r_{12} & \ldots & r_{1 n} \\
r_{21} & r_{22} & \ldots & r_{2 n} \\
\cdot & & & \cdot \\
\cdot & & & \cdot \\
\cdot & & & \cdot \\
r_{m 1} & r_{m 2} & \ldots & r_{m n}
\end{array}\right]
$$


Adım 3: Ağırlıklı normalize karar matrisinin oluşturulması

$\mathrm{Bu}$ adımda öncelikle değerlendirme kriterlerine (finansal oranlara) ilişkin ağırlık değerleri

$\left(w_{i}\right)$ belirlenir.

$$
\left(\sum_{i=1}^{n} w_{i}=1\right)
$$

Daha sonra $R$ matrisinin her bir sütunundaki elemanlar ilgili ağırlık değeri ile çarpılarak $V$ ağırlıklı karar matrisi oluşturulur:

$V_{i j}=\left[\begin{array}{cccc}w_{1} r_{11} & w_{2} r_{12} & \ldots & w_{n} r_{1 n} \\ w_{1} r_{21} & w_{2} r_{22} & \ldots & w_{n} r_{2 n} \\ \cdot & & & \cdot \\ \cdot & & & \cdot \\ \cdot & & & \cdot \\ w_{1} r_{m 1} & w_{2} r_{m 2} & \ldots & w_{n} r_{m n}\end{array}\right]$

Adım 4: Ideal ve negatif ideal çözümlerin belirlenmesi

İdeal $\left(A^{*}\right)$ çözümün belirlenmesi için Eş. (5) kullanılarak ağırlıklandırılmış matriste her bir sütun için en büyük değerler (ilgili değerlendirme faktörü en küçükleme yönlü ise en küçük değer) ve negatif ideal $\left(A^{-}\right)$çözümün belirlenmesi içinse Eş. (6) kullanılarak en küçük değerler (ilgili değerlendirme faktörü en küçükleme yönlü ise en büyük değer) tespit edilir.

$A^{*}=\left\{\left(\max _{i} v_{i j} \mid j \in J\right),\left(\min _{i} v_{i j} \mid j \in J^{\prime}\right\} A^{*}=\left\{v_{1}^{*}, v_{2}^{*}, \ldots, v_{n}^{*}\right\}\right.$

$A^{-}=\left\{\left(\min _{i} v_{i j} \mid j \in J\right),\left(\max _{i} v_{i j} \mid j \in J^{\prime}\right\} A^{-}=\left\{v_{1}^{-}, v_{2}^{-}, \ldots, v_{n}^{-}\right\}(6)\right.$

Adım 5: Ideal noktaya $\left(S_{i}^{*}\right)$ ve negatif ideal noktaya

$\left(S_{i}^{-}\right)$uzaklıklar sirasıyla Eş. (7) ve Eş.

kullanilarak hesaplanır.

$S_{i}^{*}=\sqrt{\sum_{j=1}^{n}\left(v_{i j}-v_{j}^{*}\right)^{2}}$

$S_{i}^{-}=\sqrt{\sum_{j=1}^{n}\left(v_{i j}-v_{j}^{-}\right)^{2}}$

Adım 6: İdeal çözüme göreceli yakınlı̆̆ın hesaplanmasl

Her bir alternatifin ideal çözüme göreceli yakınlığının $\left(C_{i}^{*}\right)$ hesaplanmasında aşağıdaki formül kullanılır.

$$
C_{i}^{*}=\frac{S_{i}^{-}}{S_{i}^{-}+S_{i}^{*}}
$$

Burada $C_{i}^{*}$ değeri $0 \leq C_{i}^{*} \leq 1$ aralığında değer alır.

Yukarıda detayları açıklanan modele ilişkin veri tabanı ve firma derecelendirme işleminin gerçekleştirildiği TOPSIS yöntemi ilişkilendirilerek Visual Basic dili ile kodlanan bir bilgisayar uygulaması haline dönüştürülmüştür. Bilgisayar uygulamasının işletimi ve kullanılmasına ilişkin uygulama örneğine bir sonraki bölümde yer verilmiştir.

\section{GELIŞTIRILEN \\ BILGISAYAR UYGULAMASININ ADIMLARI (STEPS OF THE DEVELOPED COMPUTER APPLICATION)}

Adım 1: Kullanıcı uygulamayı açtıktan sonra ilk önce değerlendirmenin yapılacağ 1 sektörün seçimi yapmalıdır (Şekil 1).

Adım 2: İlgili sektör seçimi (Örneğin Teknoloji-Bkz. Şekil 1) gerçekleştirildikten sonra "Onay" butonuna basıldığında yeni firma ekleme ekranı görüntülenir (Şekil 2).

Burada eğer kullanıcı veri tabanında mevcut olmayan yeni bir firmayı (örneğin $\mathrm{ABC}$ : gizlilik ilkeleri nedeniyle firmanın ismi gizli tutulmuştur) ilgili sektördeki diğer firmaların arasına ekleyerek değerlendirmeye dâhil etmek isterse, firmanın finansal oran verilerini Şekil 3'te verilen ekranları kullanarak girebilir.

Adım 3: Kullanıcı Seçimi: Geliştirilen uygulama farklı türde kullanıcılara hitap edecek şekilde yapılandırılmıştır. Finansal performans derecelendirme işlemine ihtiyaç duyan farklı kurum/kuruluş/kişiler bulunabilmektedir. Bunları bankalar, yatırımcılar ve firmalar olmak üzere 3 temel gruba ayırabiliriz.

Örneğin bankalar açısından özellikle kredi değerlendirme faaliyeti düşünüldüğünde, firmaların derecelendirilmesinde finansal yapı oranlarının ve faaliyet oranlarının diğer oranlar göre daha fazla önemli olduğu bilinmektedir. Yatırımcılar açısından ise firmaların karlılığı, dolayısıyla karlılık oranlarının diğer oranlara göre daha önemli olduğu, firmaların kendi performanslarını değerlendirmelerinde ise karlılık ve likidite oranlarının diğer oranlara göre daha önemli oranlar olduğu söylenebilir. Kullanıcı bazında bu farklılıklar dikkate alınarak her bir grup için ayrı finansal oran ağırlıkları belirlenmiştir (Şekil 4-6). 


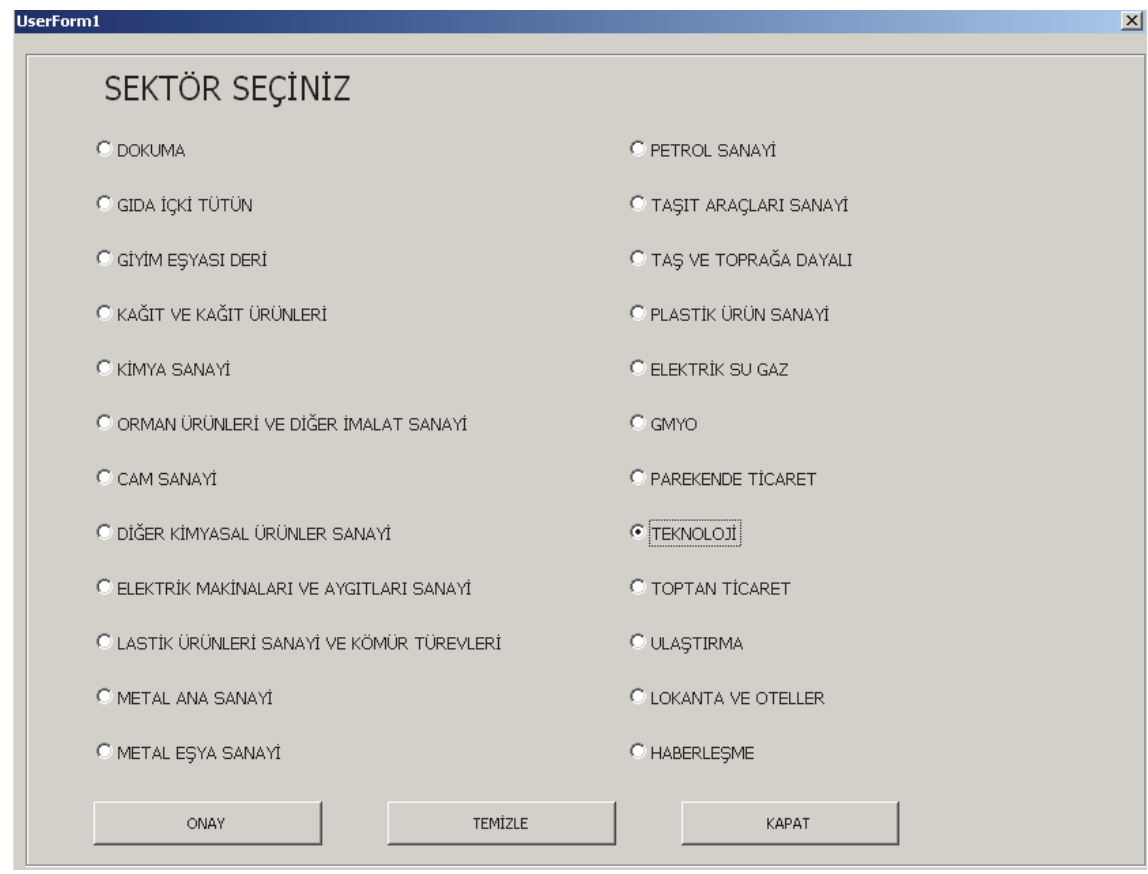

Şekil 1.Sektör seçimi (Sector selection)

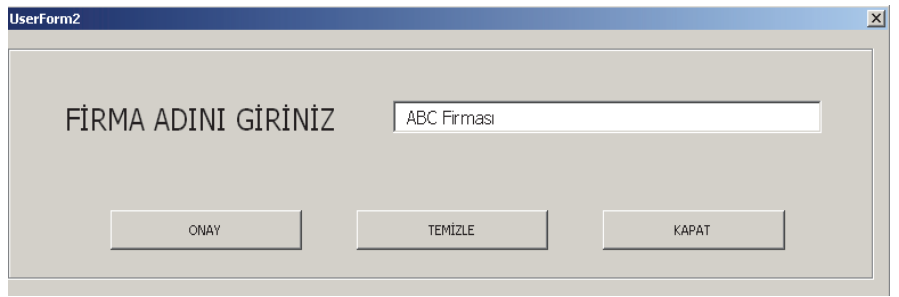

Şekil 2. Yeni firmanın modele giriş ekranı (The input screen of the model for the new applicant firm)

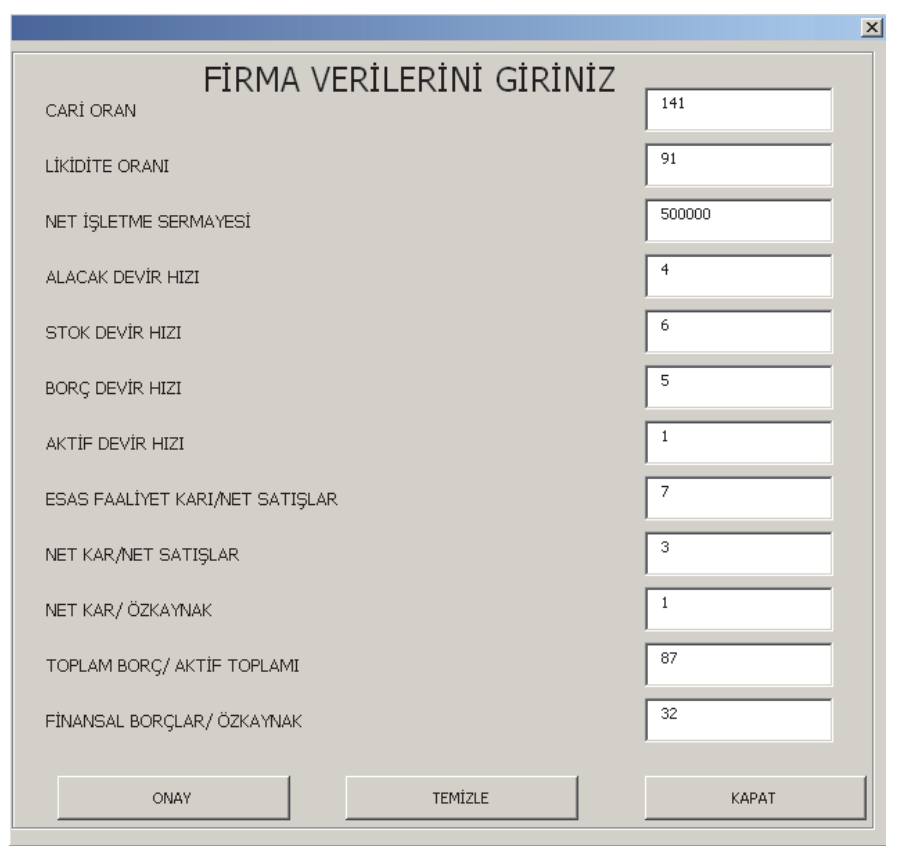

Şekil 3. Yeni firmanın finansal verilerinin modele giriş ekranı (The input screen of the model for the new applicant firm's financial values) 


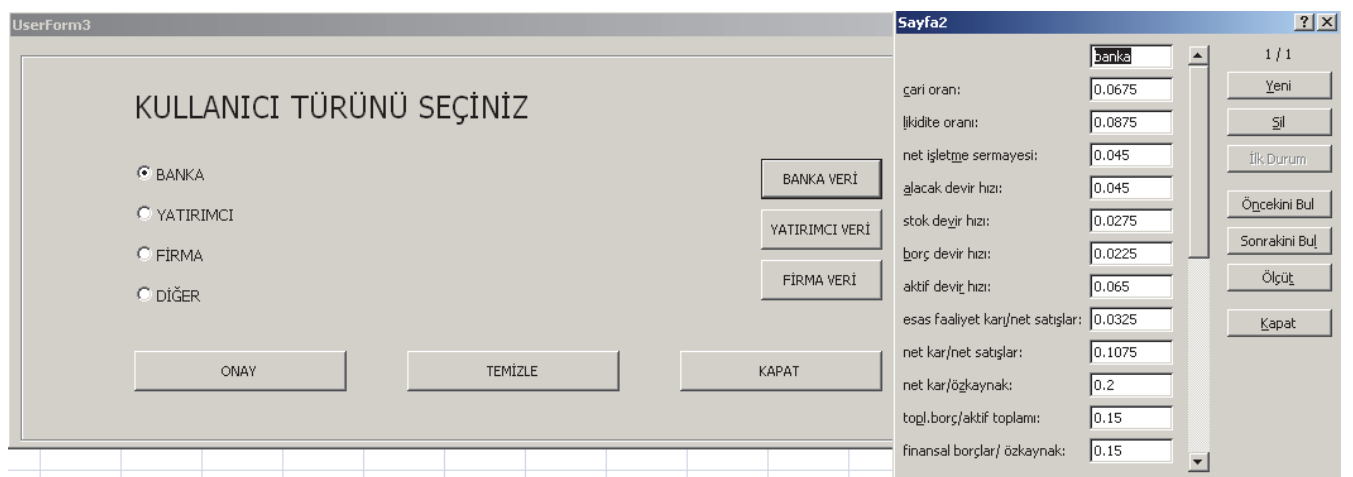

Şekil 4. Kullanıcı türüne göre önceden belirlenmiş kriter ağırlıkları: Banka (Pre-determined criteria weights based on the selected user type: Bank)

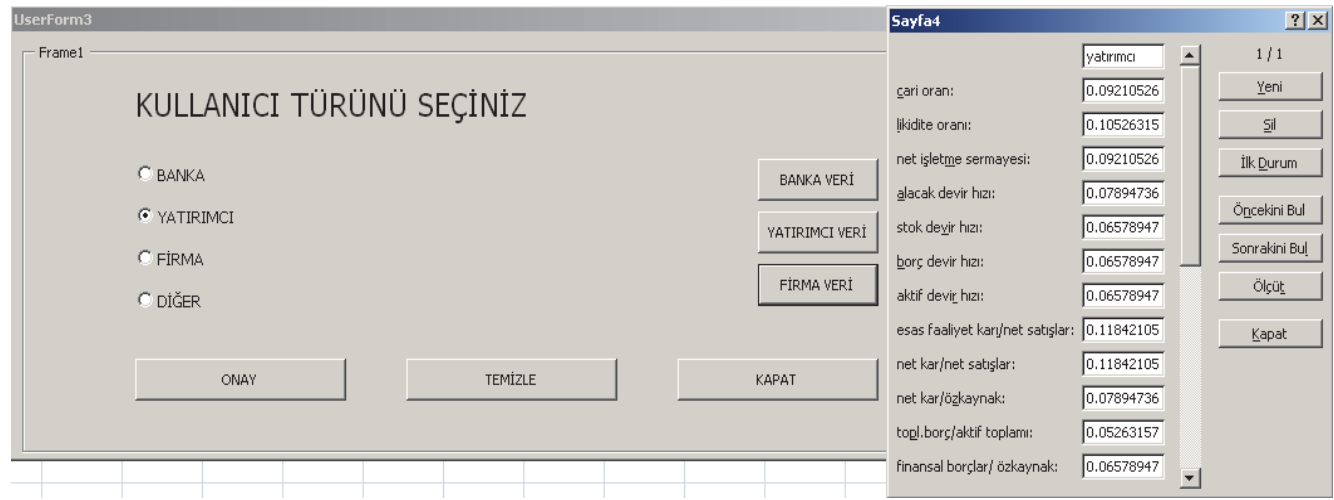

Şekil 5. Kullanıcı türüne göre önceden belirlenmiş kriter ağırlıkları: Yatırımcı (Pre-determined criteria weights based on the selected user type: Investor)

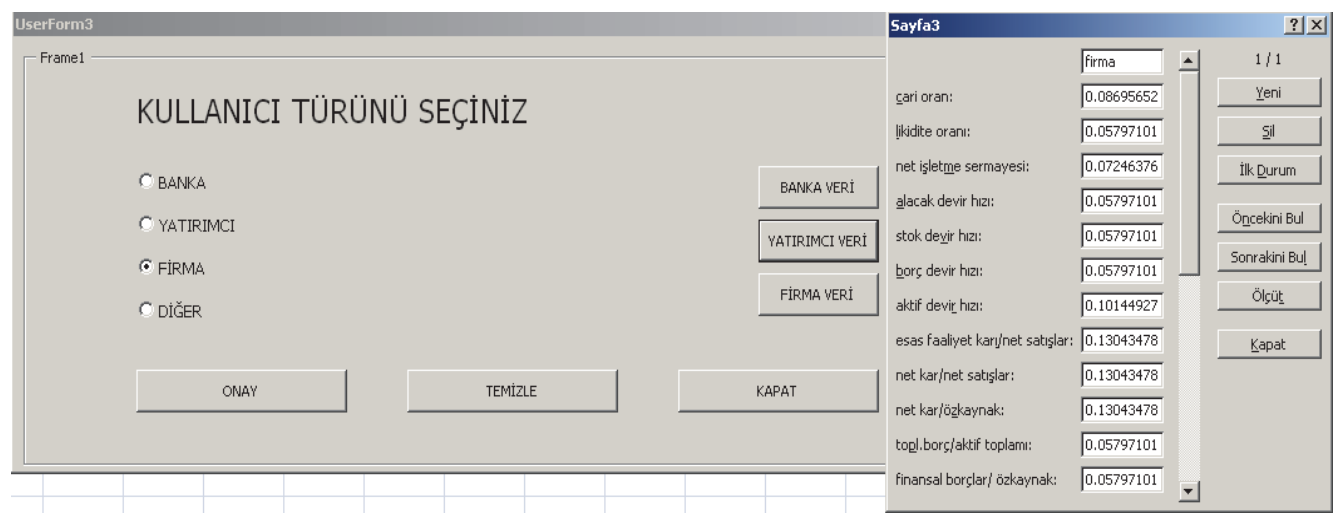

Şekil 6. Kullanıcı türüne göre önceden belirlenmiş kriter ağırlıkları: Firma. (Pre-determined criteria weights based on the selected user type: Firm)

Finansal oranlar ve oranların ağırlıkları belirlenirken Türk Bankacılık Sektöründeki Türkiye'nin en büyük bankalarından bir tanesinin finansal analiz biriminde çalışan 3 uzmanın (birim müdürü, yönetmen ve finansal analiz uzmanı), deneyimlerinden faydalanılmıştır. Uzmanların her bir kullanıcı grubu için finansal oranlara verdikleri ağırlık değerlerinin geometrik ortalaması alınarak finansal oran ağırlıkları belirlenmiştir.

Belirlenen finansal oran ağılıkları TOPSIS yöntemi uygulama adımları-Adım 3'te belirtildiği şekilde normalize edilerek kullanılmıștır. Ağırlıkların belirlenmesinde TOPSIS yöntemini geliștiren Hwang ve Yoon'un 10 puan ölçeği kullanılmıştır (Çizelge 2).

Çizelge 2. Kriter ağırlıklarının atanması için 10 puan ölçeği (10-point scaleforassignment of criteriaweights) [15]

Kriterin Değerlendirilmesi Rakamsal Değeri

\begin{tabular}{ll}
\hline En önemsiz & 0 \\
Çok önemsiz & 1 \\
Önemsiz & 3 \\
Orta önemde & 5 \\
Önemli & 7 \\
Çok önemli & 9 \\
En önemli & 10
\end{tabular}


Kullanıcı hangi kullanıcı grubunu seçerse o grup için belirli kriter ağırlıkları otomatik olarak kullanılarak firma sıralaması elde edilebilmektedir. Bu üç gruptan hiç birini kullanmak istemeyen ve kriter ağırlıklarını kendisi belirlemek isteyen kullanıcılar içinse "diğer" seçeneği seçildiğinde kriter ağırlıklarının kullanıcı tarafindan verilebildiği ekran görüntülenmektedir (Şekil 7). Kullanıcı bu ekranda kriter ağırlıklarını girdikten sonra "onay" butonuna bastığında firmaların sıralanmış halini kendi belirlediği kriter ağırlıkları doğrultusunda tespit edebilmektedir. (Şekil 8).

Kullanıcı Şekil 1 ve Şekil 2'deki ekranları kullanarak belirlediği tüm aday firmaları, Şekil 4'te hangi kullanıcı grubunu seçtiyse (örneğin Banka) o grup için bilgisayar uygulamasında önceden belirlenmiş ve kayıtlı olan ağırlıklara göre siralamaktadır. Eğer kullanıcı sıraladığı firmaları başka bir kullanıcı grubu için (örneğin Yatırımcı veya Firma) yeniden sıralamak isterse, bu sefer Şekil 4'teki kullanıcı gruplarından diğer bir tanesini seçerek sıralama gerçekleştirebilir. $\mathrm{Bu}$ durumda bilgisayar uygulamasında kayıtlı olan firma (çalışma içeriğinde bahsi geçen ABC firması) ile firmanın karşılaştırılacağı diğer aday firmaların (sektördeki diğer firmalar) seçilen kullanıcı grubu doğrultusunda otomatik olarak değerlendirme grubu değişmektedir (örneğin ilk sıralamada Banka kullanıcı grubunda değerlendirilirken, Yatırımcı veya Firma kullanıcı grubunda değerlendirilecektir).

Burada değerlendirme yapılan firmaların sayılarında ve değerlendirme verilerinde bir değişiklik olmayıp, seçilen kullanıcı grubu doğrultusunda kriterlerin ağırlıkları otomatik olarak değişmekte ve yeniden siralama gerçekleştirilmektedir.

Şekil 9-11'de sırasıyla deneme yapılan ve veri girişi gerçekleştirilen (Şekil 3) "ABC” firmasının "Banka Kullanıcısı", "Yatırımcı Kullanıcısı" ve "Firma Kullanıcısı" bazında derecelendirilme sonuçları verilmiştir. $\mathrm{Bu}$ sonuca göre $\mathrm{ABC}$ firması; banka kullanıcıs1 uygulamasinda 13. sirada, firma kullanıcıs1 uygulamasinda 8 . sirada ve yatırımcı kullanıcısı uygulamalarında ise 10 . sırada yer almıştır.

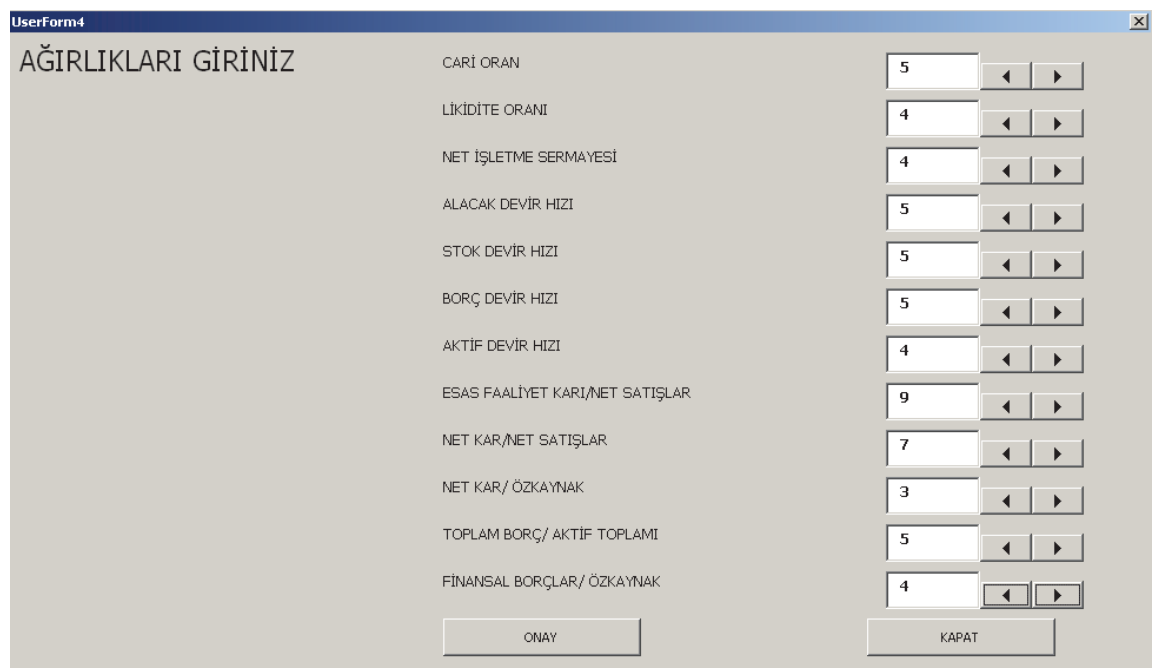

Şekil 7. Finansal oranların ağırlık giriş ekranı (Input screen for the weights of the financial ratios )

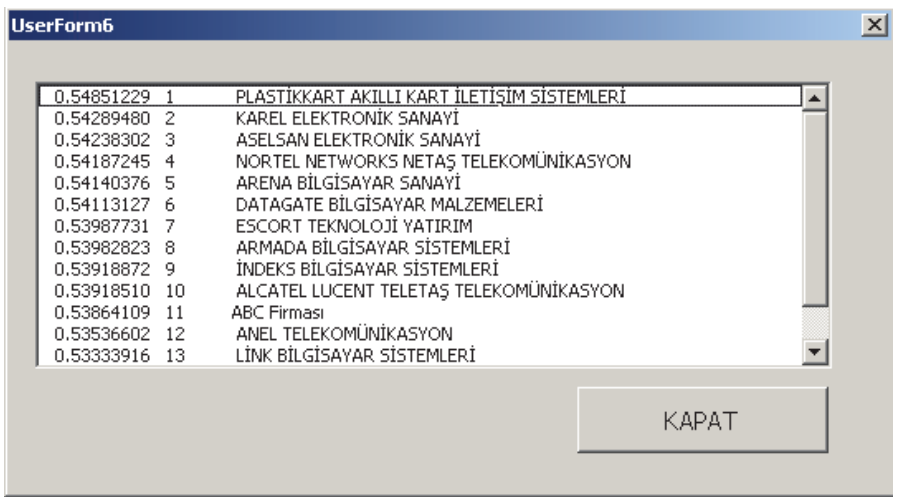

Şekil 8. Modelin çıktı ekranı (Output screen of the model) 


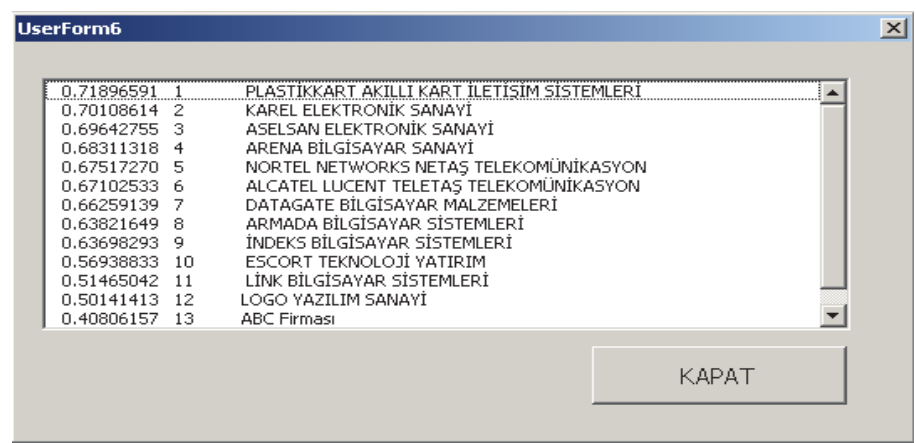

Şekil 9. Banka tipi kullanıcı için firma derecelendirme (Firm ratings for the bank type user)

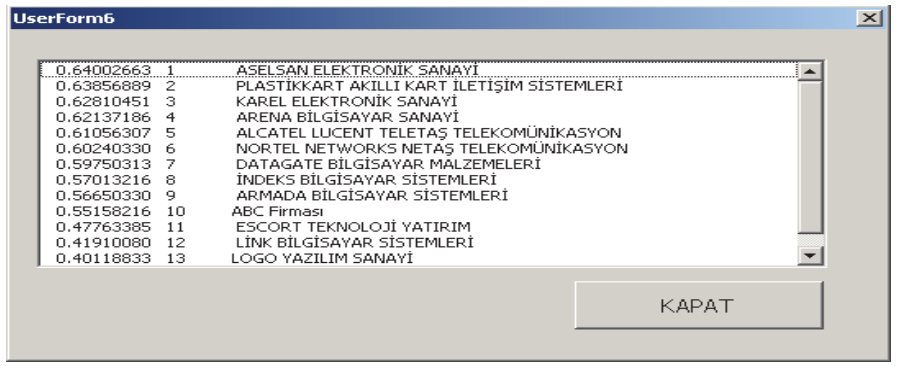

Şekil 10. Yatırımcı tipi kullanıcı için firma derecelendirme (Firm ratings for the investor)

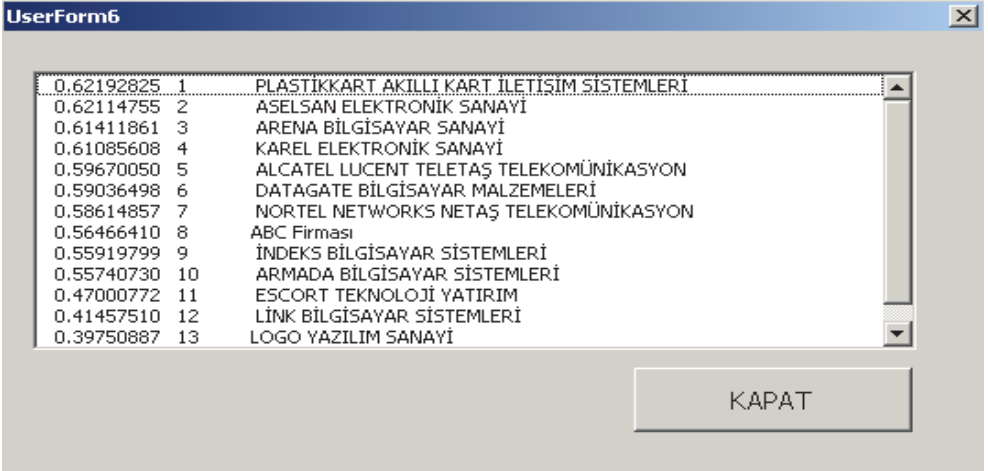

Şekil 11. Firma tipi kullanıcı için firma derecelendirme (Firm ratings for the firm type user)

\section{TARTIŞMA (DISCUSSION)}

$\mathrm{Bu}$ bölümde çalışmamızda geliştirilen modelin kullanılabilirliği tartışılmış ve test edilmiştir.

Bu amaçla, çalışmada geliştirilen model kullanılarak BİST'te işlem gören teknoloji firmaları için üç farklı kullanıcı grubuna göre elde edilen TOPSIS firma sıralama sonuçları, teknoloji firmalarının hisse senetleri değerlerine göre belirlenen "pazar değerleri" sıralanmaları ile karşılaştırılmıştır (Çizelge 3). Sıralamaların karşılaştırılması amacıyla Spearman'ın Sıra İlişkisi Testi [34] kullanılmıştır.

Spearman'ın Sıra İlişkisi Testi’ne göre iki sıralama arasındaki tutarlılıktan bahsedilmek için, Eş.(10-11) kullanılarak elde edilen test istatistiği Z'nin değerinin $\% 95$ güven düzeyinde $(\alpha=0,05) 1,645$ 'in üzerinde olması beklenmektedir [34].

$r_{s}=1-\frac{6 \sum_{j=1}^{K}\left(d_{j}\right)^{2}}{K\left(K^{2}-1\right)}$

$$
Z=r_{s} \sqrt{(K-1)}
$$

Eşitliklerde $d_{j}$, sıralama tutarlılığı analiz edilen iki farklı yöntemden elde edilen $\mathrm{j}$ firmasının sıralama farkını; K, firma sayısını ve $r_{s}$, Spearman'nın sıra ilişkisi katsayısını ifade eder.

Spearman'ın Sıra İlişkisi Testi sonuçlarına göre firmaların pazar değerlerine göre siralamaları ve geliştirilen modelin "yatırımcı" kullanıcı grubuna göre sıralama sonuçları arasında tutarlılık bulunduğu söylenebilir (Bkz. Çizelge 3: Z=1,73).

"Banka" ve "firma" kullanıcı gruplarında ise sıralamalar arasındaki tutarlılığın düşük olduğu söylenebilir. Genel olarak hisse senetlerine yatırım yapan yatırımcıların yatırım kararlarındaki temel beklentisi hisse senedi satın alınan firmaların faaliyetlerinde başarılı olması ve karlılıklarındaki olumlu yönde gelişme beklentisidir. 
Çizelge 3. Firma sıralamalarının karşılaştırılması (Comparison of firm rankings)

\begin{tabular}{|c|c|c|c|c|c|c|c|c|}
\hline \multirow[b]{2}{*}{ Teknoloji Firmaları } & \multicolumn{3}{|c|}{$\begin{array}{l}\text { Geliştirilen Modelin } \\
\text { TOPSIS Sıralama Sonuçları }\end{array}$} & \multirow{2}{*}{$\begin{array}{c}\text { Firmaların } \\
\text { Pazar Değeri* } \\
\text { [22] }\end{array}$} & \multirow{2}{*}{$\begin{array}{c}\text { Pazar } \\
\text { Değeri } \\
\text { Siras1 } \\
(\mathrm{PD})\end{array}$} & \multicolumn{3}{|c|}{ Siralama Fark1 } \\
\hline & $\begin{array}{l}\text { Banka } \\
\text { (B) }\end{array}$ & $\begin{array}{c}\text { Firma } \\
(\mathrm{F})\end{array}$ & $\begin{array}{l}\text { Yatırım } \\
(\mathrm{Y})\end{array}$ & & & B-PD & $\begin{array}{c}\text { F- } \\
\text { PD }\end{array}$ & $\begin{array}{l}\text { Y- } \\
\text { PD }\end{array}$ \\
\hline AlcatelTeletaş Telekomünikasyon & 6 & 5 & 5 & 111845,2 & 4 & 2 & -1 & -1 \\
\hline Anel Telekomünikasyon & 13 & 13 & 13 & 43000 & 9 & 4 & -4 & -4 \\
\hline Arena Bilgisayar Sanayi & 4 & 3 & 4 & 75520 & 7 & -3 & 4 & 3 \\
\hline Armada Bilgisayar Sistemleri & 8 & 9 & 9 & 35040 & 11 & -3 & 2 & 2 \\
\hline Aselsan Elektronik Sanayi & 3 & 2 & 1 & 1928837 & 1 & 2 & -1 & 0 \\
\hline Datagate Bilgisayar Malzemeleri & 7 & 6 & 7 & 22800 & 12 & -5 & 6 & 5 \\
\hline Escort Teknoloji Yatırım & 10 & 10 & 10 & 146909,3 & 3 & 7 & -7 & -7 \\
\hline İndeks Bilgisayar Sistemleri & 9 & 8 & 8 & 128800 & 5 & 4 & -3 & -3 \\
\hline Karel Elektronik Sanayi & 2 & 4 & 3 & 122400 & 6 & -4 & 2 & 3 \\
\hline Link Bilgisayar Sistemleri & 11 & 11 & 11 & 21670 & 13 & -2 & 2 & 2 \\
\hline Logo Yazılım Sanayi & 12 & 12 & 12 & 37750 & 10 & 2 & -2 & -2 \\
\hline Nortel-Netaş Telekomünikasyon & 5 & 7 & 6 & 794593,8 & 2 & 3 & -5 & -4 \\
\hline Plastikkart Akıllı Kart İletişim Sistemleri & 1 & 1 & 2 & 49595 & 8 & -7 & 7 & 6 \\
\hline \multicolumn{6}{|c|}{ Spearman'ın sıra ilişki katsayısı $\left(\mathrm{r}_{\mathrm{s}}\right)$} & 0,412 & 0,401 & 0,500 \\
\hline & & & & & $\mathbf{Z}$ & 1,43 & 1,39 & 1,73 \\
\hline
\end{tabular}

*Pazar Değeri= $($ Firmanın hisse senedinin yıl sonu kapanış değeri*Ödenmiş Sermaye)/1000 [1,22]

$\mathrm{Bu}$ doğrultuda TOPSIS modelinde "yatırımcı" kullanıcı grubu için finansal oran ağırlıkları da bu beklenti doğrultusunda karlılık ve faaliyet oranlarına, finansal yapı oranlarından daha fazla ağırlık verilerek gerçekleştirilmeye çalışılmıştır. Bunun bir sonucu olarak da yatırımcı kullanıcı grubu için TOPSIS sıralama sonuçları ile firmaların pazar değerleri sıralamalarında bir tutarlılık elde edilebilmiştir.

Diğer roller olan "banka" ve "firma" kullanıcıları ile pazar değeri sıralamasının tutarlı olmaması beklenen bir durumdur. Çünkü banka ve firma kullanıcıları için kriter ağırlıkları bankaların kredi verecekleri firmaları, firmaların ise kendi performanslarını değerlendirmedeki önceliklerine göre kriter ağırlıkları belirlenerek oluşturulmuştur.

Örneğin banka kullanıcısı için bankanın kendi politikaları doğrultusunda geliştirdiği bir finansal analiz sisteminden elde edilecek sıralama sonuçlarıyla aynı firmaların makalede geliştirilen "banka" kullanıcısına göre sıralanma sonuçlarının karşılaştırılarak tutarlılık analizi yapılması anlamlıdır. Ancak bu analiz için bankaların firmaların finansal analizini gerçekleştirdikleri sistemlerinin sonuçlarını gizlilik kuralları doğrultusunda analize açmamaları dolayısıyla bu tür bir analiz makalede gerçekleştirilememiştir.

Başka bir karşılaştırma işlemi olarak, literatürde kullanılan diğer ÇKKV yöntemlerinden olan VIKOR,
GRA ve MOORA yöntemleriyle de teknoloji firmaları sıralanmış ve elde edilen sıralama sonuçları pazar değeri sıralamasıyla yine Spearman'ın Sira İlişkisi Testi kullanılarak sıralama tutarlılığı ölçülmüştür.

Opricovic ve Tzeng tarafindan geliştirilen VIKOR yöntemi, alternatiflerin kriterlerin pozitif ve negatif ideal çözümlerine uzaklığının uzlaşma katsayısı (v) kullanılarak hesaplandığı ve bu hesaplama sonuçlarına göre alternatiflerin sıralandığı bir ÇKKV yöntemidir [35]. VIKOR yöntemi uygulaması sonucunda ulaşılan uzlaşık çözüm, çoğunluğun en büyük grup faydasını ( $>0,5)$, çoğunluğa karşıt görüşleri $(\mathrm{v}<0,5)$ dikkate alarak veya çoğunluğun görüşü ile karşıt görüşlüler arasında uzlaşmayı $(\mathrm{v}=0,5)$ dikkate alarak sıralama gerçekleştirilebilen bir yöntemdir. Bir başka ifadeyle $\mathrm{v}=0,5$; pozitif ideal (çoğunluğun görüşü) ve negatif ideal çözüme (karşıt görüş) eşit mesafedeki alternatifleri sıralamada üst sıralara yerleştirmeye çalışıldığını ifade eder.

1982'de Julong Deng'in[36] ifade ettiği "gri sistem teorisi”; gri tahmin, gri karar verme, gri ilişkisel analiz gibi alt konu başlıkları altında uygulama alanı bulmaktadır. Gri ilişkisel analiz, gri bir sistemdeki her bir kriter ile kiyaslanan bir referans kriter serisinin ilişki derecesini belirlemeye yarayan bir yöntemdir. Kriterler bir dizi olarak tanımlanarak, kriterler arasındaki etkileşim mertebesinin düzeyi ise gri ilişkisel derece olarak adlandırılır [37]. 
Gri teoride kriter değerlerinin normalizasyon süreci "gri ilişkisel oluşum" olarak isimlendirilir. Kriter değerleri normalize edilirken kriter serisinin " en büyük en iyi”, "en küçük en iyi" ve "nominal en iyi”" önermelerinden hangisine uygun olduğunun bilinerek normalizasyon işleminde uygun eşitliğin kullanılması gerekir.

$\mathrm{k}$, n uzunluğundaki serideki k. sırayı göstermek üzere k. noktadaki gri ilişkisel katsayı olup, $\xi \in(0,1)$ arasındaki bir ayrım katsayı kullanılarak (çoğunlukla orta değer olan 0,5 değeri alınarak) hesaplanır [37]. Gri ilişkisel katsayı yardımıyla ve kriterlerin önem ağırlıkları kullanılarak gri ilişkisel derece hesaplanır. Gri ilişkisel derece, referans seriyle karşılaştırılan serinin benzerliğinin ölçüsüdür. Gri ilişkisel derecesi en büyük olan alternatif en iyi alternatifi belirtir.

Brauers [11] tarafindan 2004 yılında geliştirilen MOORA yöntemi ise birçok amaçlı en iyileme yöntemidir. TOPSIS, VIKOR ve GRA yöntemine göre çok daha yeni bir yöntem olan ve uygulama adımları çok daha basit ve kolay anlaşılır MOORA yönteminin uygulama adımları aşağıda verilmektedir [32]:

Adım 1: Finansal oranlar kullanılarak karar matrisi oluşturulur.

$$
X=\left[\begin{array}{cccc}
x_{11} & x_{12} & \ldots & x_{1 n} \\
x_{21} & x_{22} & \ldots & x_{2 n} \\
\ldots & \ldots & \ldots & \ldots \\
x_{m 1} & x_{m 2} & \ldots & x_{m n}
\end{array}\right]
$$

Matriste $x_{i j} i$. firmanın $j$. finansal oran değerini, $m$ firma sayısını, $n$ ise finansal oran sayısını ifade eder.

Adım 2: Normalize karar matrisi Eş.(13)'deki gibi oluşturulur:

$$
x_{i j}^{*}=\frac{x_{i j}}{\sqrt{\sum_{i=1}^{m} x_{i j}^{2}}} \quad(j=1,2, \ldots, n)
$$

Burada $x_{i j}^{*}[0,1]$ arasında ifade edilen i. Firmanın j. finansal oranının birimden bağımsız normalize değerini gösterir.

Adım 3: Normalize finansal oran değeri en büyükleme durumunda toplanır (getiri türü finansal oranlar için), enküçükleme durumunda (maliyet türü finansal oranlar için) çıkarılarak firmaların tüm finansal oranlar bazında siralama puanını temsil eden MOORA indeksi ( $\mathrm{Y}_{\mathrm{i}}$ ) hesaplanır (Eş. 14).
$Y_{i}=\sum_{j=1}^{g} x_{i j}^{*}-\sum_{j=g+1}^{n} x_{i j}^{*}$

Burada gen büyüklenmek istenen finansal oran sayısını, $(n-g)$ en küçüklenmek istenen finansal oran sayısını ifade eder. Finansal oranlara (kriterlere) ağırlık verilmesi durumunda, her bir finansal oranın ağırlık değeri, finansal oranın normalize edilmiş değeriyle çarpılır ve bu durumda Eş.(15) aşağıdaki gibi ifade edilir:

$Y_{i}=\sum_{j=1}^{g} w_{j} x_{i j}^{*}-\sum_{j=g+1}^{n} w_{j} x_{i j}^{*}(j=1,2 . . n)$

VIKOR, GRA ve MOORA yöntemleriyle sıralama sonuçlarının elde edilmesinde TOPSIS yönteminde olduğu gibi "yatırımcı" kullanıcı türüyle işlem gerçekleştirilmiştir.

Diğer tarafta VIKOR yönteminin uzlaşma parametresi " $v$ " [5, 35, 37] ve GRA yöntemindeki ayrım katsayıs1 " $\xi$ "yöntemlerin uzlaşık çözüm ve gri sistem teorisi felsefelerine uygun olarak 0,5 [26-28, 37] alınarak sıralama sonuçları elde edilmiştir.

Çizelge 4 incelendiğinde her üç yönteminde pazar değeri sıralamasıyla tutarlılık gösteremediği görülmektedir (VIKOR yöntemi için $Z=1,637<1,645$; GRA yöntemi için $Z=1,18<1,645$;MOORA yöntemi için $Z=1,389$ ).

Elde edilen bu sonuç, TOPSIS, VIKOR, GRA ve MOORA yöntemleri arasında finansal performans derecelendirme işleminde pazar değeri sıralamasıyla en tutarlı sıralamayı veren yöntemin TOPSIS yöntemi olduğunu göstermektedir. $\mathrm{Bu}$ sonuç ayrıca çalışmamızda geliştirilen finansal performans derecelendirme modelinde kullanılan TOPSIS modelinin iyi bir seçim olduğunun da bir göstergesidir.

TOPSIS yönteminin VIKOR, GRA, MOORA yöntemlerine göre finansal performans değerlendirmede daha iyi sonuçlar vermesinin en önemli nedeninin TOPSIS yönteminin alternatifler içerisinde kriterlerin pozitif ideal değerlerine daha yakın olanları sıralamada üst sıralara yerleştirme prensibinden kaynaklandığı söylenebilir. Bu prensip Eş. (9)'da açık olarak görülebilmektedir. Eş. (9)'a göre $\mathrm{i}$ alternatifinin $\mathrm{C}_{\mathrm{i}}{ }^{*}$ değerinin yüksek olması, $\mathrm{S}_{\mathrm{i}}^{-}$ değerinin diğer alternatiflerin $\mathrm{S}_{\mathrm{i}}^{-}$değerinden daha büyük olmasıyla (negatif ideal noktaya daha uzak), diğer yönden $\mathrm{S}_{\mathrm{i}}{ }^{*}$ değerinin diğer alternatiflerin $\mathrm{S}_{\mathrm{i}}{ }^{*}$ değerinden daha düşük olmasıyla (pozitif ideal noktaya daha yakın olma) sağlanabilir. Diğer taraftan VIKOR yönteminde uzlaşık çözüm felsefesi gereği pozitif ve negatif ideal noktalara eşit mesafede; veya GRA yönteminde gri bölgede olan alternatifler diğer alternatiflere göre daha üst sırada yer alması tavsiye edilmektedir. 
Çizelge 4. Firma sıralamalarının karşılaştırılması: Pazar Değeri-VIKOR-GRA-MOORA (Comparison of firm rankings: Market Value-VIKOR-GRA-MOORA)

\begin{tabular}{|c|c|c|c|c|c|c|c|c|c|c|c|}
\hline \multirow{3}{*}{ Teknoloji Firmaları } & \multirow{3}{*}{$\begin{array}{c}\text { Pazar } \\
\text { Değeri } \\
(\mathrm{PD})\end{array}$} & \multirow{3}{*}{ Sira } & \multicolumn{2}{|c|}{ VIKOR } & \multicolumn{2}{|c|}{ GRA } & \multicolumn{2}{|c|}{ MOORA } & \multirow{2}{*}{\multicolumn{3}{|c|}{ Suralama Farkı }} \\
\hline & & & \multirow{2}{*}{$\begin{array}{c}\text { VIKOR } \\
\text { Puanı (P) }\end{array}$} & \multirow{2}{*}{ Sira } & \multirow{2}{*}{$\begin{array}{c}\text { Gri İlişki } \\
\text { Derecesi } \\
\text { (GİD) }\end{array}$} & \multirow{2}{*}{ Sira } & \multirow{2}{*}{$\begin{array}{l}\text { MOORA } \\
\text { Puanı (Y) }\end{array}$} & \multirow{2}{*}{ Sira } & & & \\
\hline & & & & & & & & & PD-P & PD-GİD & PD-Y \\
\hline Alcatel T.T & 111845,2 & 4 & 0,30747 & 7 & 0,50612 & 8 & 0,0927 & 7 & -3 & -4 & -3 \\
\hline Anel T. & 43000 & 9 & 0,69924 & 11 & 0,410128 & 13 & $-0,0577$ & 12 & -2 & -4 & -3 \\
\hline Arena B.S. & 75520 & 7 & 0,25018 & 5 & 0,557665 & 3 & 0,1345 & 4 & 2 & 4 & 3 \\
\hline Armada B.S. & 35040 & 11 & 0,31246 & 8 & 0,496144 & 10 & 0,0890 & 8 & 3 & 1 & 3 \\
\hline Aselsan E.S. & 1928837 & 1 & 0,00000 & 2 & 0,638227 & 2 & 0,2288 & 2 & -1 & -1 & -1 \\
\hline Datagate B.M. & 22800 & 12 & 0,25833 & 6 & 0,536383 & 5 & 0,1237 & 6 & 6 & 7 & 6 \\
\hline Escort T.Y. & 146909,3 & 3 & 0,59650 & 10 & 0,512465 & 7 & 0,0292 & 10 & -7 & -4 & -7 \\
\hline İndeks B.S. & 128800 & 5 & 0,38429 & 9 & 0,490332 & 11 & 0,0851 & 9 & -4 & -6 & -4 \\
\hline Karel E.S. & 122400 & 6 & 0,19690 & 4 & 0,555255 & 4 & 0,1348 & 3 & 2 & 2 & 3 \\
\hline Link B.S. & 21670 & 13 & 0,82841 & 12 & 0,497506 & 9 & $-0,0135$ & 11 & 1 & 4 & 2 \\
\hline Logo Y.S. & 37750 & 10 & 0,98602 & 13 & 0,427407 & 12 & $-0,0877$ & 13 & -3 & -2 & -3 \\
\hline Nortel N.T. & 794593,8 & 2 & 0,11044 & 3 & 0,536267 & 6 & 0,1273 & 5 & -1 & -4 & -3 \\
\hline Plastikkart A.K.İ.S & 49595 & 8 & $-0,09776$ & 1 & 0,696071 & 1 & 0,2810 & 1 & 7 & 7 & 7 \\
\hline \multicolumn{9}{|c|}{ Spearman'ın sıra ilişki katsayısı $\left(r_{s}\right)$} & 0,473 & 0,341 & 0,401 \\
\hline & & & & & & & & $\mathbf{Z}$ & 1,637 & 1,180 & 1,389 \\
\hline
\end{tabular}

Finansal analizde ise daima firmaların finansal oranlarının pozitif ideal çözüme yakın olması arzu edilir (örneğin maksimum kar, minimum borçluluk gibi). Dolayısıyla TOPSIS yöntemi VIKOR ve GRA yöntemlerine göre finansal performans ölçümü açısından daha elverişli bir yöntem olarak nitelendirilebilir. Farklı problem tipleri düşünüldüğünde örneğin kriterlerin iki farklı uç değer aralığında değerler alabildiği durumlarda(örneğin belli bir uygulama için seçilecek bir malzemenin kullanım şartlarındaki ideal çalışma sıcaklığının $-50{ }^{0} \mathrm{C}$ ila 50 ${ }^{0} \mathrm{C}$ arasında olması) TOPSIS yöntemindense VIKOR $(v=0,5)$ veya GRA $(\xi=0,5)$ yöntemleriyle uzlaşık seçim felsefesini kullanmak daha uygun bir alternatif sıralaması elde edilmesini sağlayabilir. Diğer taraftan TOPSIS yöntemine göre daha kısa ve basit bir çözüm sunan MOORA metodunda ideal çözüme uzaklık prensibi kullanılmayıp, her bir alternatifin toplamda tüm kriterleri sağlama düzeylerinin tek bir rakamla ifade edildiği sıralama puanları kullanılmaktadır. $\mathrm{Bu}$ yöntemin finansal performans ölçümünde kullanılmasının dezavantajı, alternatiflerin ideal çözüme mesafelerine göre sıralanmaları yaklaşımının gerçekleştirmemesidir. Örneğin TOPSIS yönteminde her bir kriter için belli ideal çözümler önceden belirlenirse (karlılık kriterlerine belirli eşik değerler vererek pozitif idealin belirlenmesi gibi) firmaların aldıkları sıralama puanlarının olması gereken en iyi duruma göre kıyaslanabilmesi de mümkün olabilir. Dolayısıyla pozitif ideal çözüme daha yakın, negatif ideal çözümü ise daha uzak olan alternatifleri sıralamada üst sıralara yerleştirme prensibini kullanan
TOPSIS yönteminin yukarıda açıklananlar ışığında VIKOR, GRA ve MOORA yöntemine göre finansal performans değerlendirme çalışmaları için daha uygun bir yöntem olduğu söylenebilir.

\section{SONUÇLAR (CONCLUSIONS)}

Bu çalışmada Türkiye'de faaliyet gösteren kurumsal firmalarının ait oldukları sektör içerisinde finansal başarı performanslarına göre sıralanmasının gerçekleştirildiği bir model geliştirilmiştir.

Literatürdeki çalışmalarda dikkat çeken önemli bir husus, çalışmaların belirli sektörlerdeki firmalarla sınırlandırılmasıdır. Bu çalışmalarda çimento veya otomotiv gibi belirli sektörlerdeki firmaların finansal performansları ölçülmüştür. Bunun dıșında örneğin Elektrik Makineleri ve Aygıtları Sanayii, Gayrimenkul Yatırım Ortaklıkları, Haberleşme veya Ulaştırma firmaları gibi farklı sektörlerdeki firmaların finansal performans ölçümüne yönelik bir çalışma bulunmamaktadır. Literatürde firma finansal performans derecelendirme işleminin gerçekleştirildiği sektörlerle birlikte çalışma gerçekleştirilmeyen sektörler de aynı model içerisinde toplanarak, toplamda 24 farklı sektörde faaliyet gösteren firmaların kendi sektörleri içerisinde performanslarının değerlendirilebileceği bir model ortaya konmuştur. Diğer taraftan geliştirilen modelin yapısı yeni sektör grupları veya firmaların modele eklenmesine olanak sağlayacak niteliktedir. Özellikle bankalar ve finansal kuruluşların geniş firma 
portföyleri sayesinde gerek sektör çeşitliliği, gerekse firma sayısı açısından modelin uygulama kapsamını daha da geliştirecek potansiyele sahip oldukları düşünülmektedir. Model kullanıldıkça her bir sektördeki firma sayısının artması ve modelin daha kullanışlı bir hale gelmesi beklenmektedir. Geliştirilen modelin, özellikle bankaların kredi pazarlama ve kredi değerlendirme faaliyetlerinde "firmaların sektörde diğer firmalara göre yerlerinin tespiti" ve "yeni değerlendirilen firmaların portföydeki mevcut firmalarla kiyaslanması" gibi faaliyetlerde oldukça faydalı bir araç olacağ 1 düşünülmektedir. Diğer taraftan model, özellikle menkul kıymetler borsasında yatırım yapmak isteyen yatırımcıların sektörler bazında firma değerlendirme faaliyetlerinde ve firmaların sektörlerindeki rakip firmalarla kendilerini kıyaslamaları konularında da kullanılabilir.

Geliştirilen modelde firma finansal performans sıralaması için TOPSIS yöntemi kullanılmış ve yeni firmaların eklenebileceği, mevcut firmaların verilerinin güncellenebileceği esnek yapıda bir bilgisayar uygulaması oluşturulmuştur. TOPSIS yönteminde bilgisayar uygulamasını kullanabilecek farklı kullanıcı gruplarına yönelik üç farklı kriter ağırlıklandırma seçeneği sunulmuş, ayrıca kriter ağırlıklarını kullanıcıların kendilerinin girebilmelerine de olanak sağlanmıştır. Geliştirilen bilgisayar uygulamasının sektörel bazda firma sayılarının artırılması, yeni sektörlerin ve bu sektördeki firmaların finansal verilerinin uygulamaya eklenmesi gibi ileriki dönemlerde geliştirilmeye açık yönleri de bulunmaktadır. Bilgisayar uygulamasının güncelliğini koruması için firmalara ait finansal verilerin en az yılda bir kez güncellenmesi ve veri tabanının güncel tutulması uygulamanın daha sağlıklı çalışması açısından dikkat edilmesi gereken hususlardır.

\section{SEMBOLLER (SYMBOLS)}

A: $\quad$ Karar Matrisi

R: $\quad$ Normalize Karar Matrisi

V: Ağırlıklı Karar Matrisi

$\mathrm{A}^{*}: \quad$ İdeal Çözüm

$\mathrm{A}^{*}$ : Negatif İdeal Çözüm

$S_{i}^{*}:$ İdeal noktaya uzaklık

$S_{i}^{-}$: Negatif ideal noktaya uzaklık

$\mathrm{C}_{\mathrm{i}}^{*}$ : İdeal çözüme göreceli yakınlık

$\mathrm{d}_{\mathrm{j}}$ : $\quad$ Siralama tutarlılığ 1 analiz edilen iki farklı

yöntemden elde edilen j firmasının sıralama farkı

K: $\quad$ Firma sayıs

$\mathrm{r}_{\mathrm{s}}: \quad$ Spearman'nın sıra ilişkisi katsayısı

Z: Test istatistiği

v: Uzlaşma katsayısı

$\xi: \quad$ Ayrım katsayısı

$Y i$ : MOORA indeksi

$x_{i j}^{*}: \quad 0-1$ arasında ifade edilen i. Firmanın j. Finansal oranının birimden bağımsız normalize değeri

\section{KAYNAKLAR (REFERENCES)}

1. Akgüç, Ö., Kredi Taleplerinin Değerlendirilmesi, Avcıol Basın-Yayın, 5.baskı, İstanbul, 1991.

2. Altman, E.I., Haldeman, R.G., ve Narayanan, P., "Zetaanalysis: A new model toidentifybankruptcy risk of corporations", Journal of Bankingand Finance, Cilt 1, 29-54, 1977.

3. Dagdeviren, M., Eraslan, E., "Prioritydetermination in strategicenergypolicies in Turkeyusinganalytic network process (ANP) withgroupdecisionmaking", International Journal Of Energy Research, Cilt 32, No 11, 1047-1057, 2008.

4. Aksakal, E., Dagdeviren, M., "An IntegratedApproachFor Personel Selection With Demateland ANP Methods", Journal of The Faculty of Engineering and Architecture of Gazi University, Cilt 25, No 4, 905-913, 2010.

5. Yalcin, N., Bayrakdaroglu, A., ve Kahraman, C., "Application of Fuzzy Multi-Criteria Decision Making Methods for Financial Performance Evaluation of Turkish Manufacturing Industries", Expert Systems with Applications, Cilt 39, 350-364, 2012.

6. Dagdeviren, M., Eraslan, E., "SupplierSelection Using PROMETHEE Sequencing Method", Journal of The Faculty of Engineering and Architecture of Gazi University, Cilt 23, No 1, 69-75, 2008.

7. Yilmaz, B., Dagdeviren, M., "Comparative Analysis of PROMETHEE andFuzzy PROMETHEE Methods in EquipmentSelection Problem", Journal of The Faculty of Engineering and Architecture of Gazi University, Cilt 25, No 4, 811-826, 2010.

8. Mostafa, M., "Benchmarking Top Arab Banks' Efficiency Through Efficient Frontier Analysis", Industrial Management and Data System, Cilt 107, No 6, 802-823, 2007.

9. Voulgaris, F., Doumpos, M., ve Zopounidis, C., "On the Evaluation of Greek Industrial SMEs' Performance via Multicriteria Analysis of Financial Ratios", Small Business Economics, Cilt 15,127-136, 2000.

10. Wang, Y.-J., Combining Grey Relation Analysis with FMCGDM to Evaluate Financial Performance of Taiwan Container Lines",Expert Systems with Applications, Cilt 36, 2424-2432, 2009.

11. Brauers, W.K.M., "Multi-Objective Seaport Planning by MOORA decision Making", Annals of Operation Research, Cilt 206, 39-58, 2013.

12. İç, Y.T., “A TOPSIS Based Design of Experiment Approach to Assess Company Ranking”, Applied Mathematics and Computation, Cilt 227, 630-647, 2014. 
13. İç. Y.T., Yurdakul, M., "Analitik Hiyerarşi Süreci (AHS) Yöntemini Kullanan Bir Kredi Değerlendirme Sistemi”, Journal of The Faculty of Engineering and Architecture of Gazi University, Cilt 15, No 1, 1-14, 2000.

14. Yurdakul, M., İç, Y.T., "AHP Approach in the Credit Evaluation of the Manufacturing Firms in Turkey", International Journal of Production Economics, Cilt 88, 269-289, 2004.

15. Yurdakul, M., İç, Y.T., "Türk Otomotiv Firmalarinin Performans Ölçümü ve Analizine Yönelik TOPSIS Yöntemini Kullanan Bir Örnek Çalışma", Journal of The Faculty of Engineering and Architecture of Gazi University, Cilt 18, No 1, 1-18, 2003.

16. Ertugrul, I., Karakasoglu, N., "Performance Evaluation of Turkish Cement Firms with Fuzzy Analytic Hierarchy Process and TOPSIS methods", Expert Systems with Applications, Cilt 36, 702-715, 2009.

17. İç. Y.T., Yurdakul, M., "Development of a QuickCredibilityScoringDecisionSupportSystem usingFuzzy TOPSIS", Expert Systems with Applications, Cilt 37, 567-574, 2010.

18. Secme N.Y., Bayrakdaroglu, A., Kahraman, C. "Fuzzy Performance Evaluation in Turkish Banking Sector using Analytic Hierarchy Process and TOPSIS", Expert Systems with Applications, Cilt 36, 11699-11709, 2009.

19. Babic, Z., Plazibat, N., "Ranking of Enterprises based on Multi Criterial Analysis", International Journal of Production Economics, Cilt 56-57, 29-35, 1998.

20. Deng, H., Yeh, C-H., ve Willis, R.J., "InterCompany Comparison using Modified TOPSIS with Objective Weights", Computers and Operation Research, Cilt 27, 963-973, 2000.

21. Moghimi, R., Anvari, A., "An Integrated Fuzzy MCDM approach and analysis to Evaluate the Financial Performance of Iranian Cement Companies", International Journal of Advanced Manufacturing Technology, Cilt 71, 685-698, 2014.

22. Bulgurcu, B., K., "Application of TOPSIS Technique for Financial Performance Evaluation of Technology Firms in Istanbul Stock Exchange Market", Procedia - Social and Behavioral Sciences, Cilt 62,1033 - 1040, 2012.

23. Feng, C-M., Wang, R-T., "Performance Evaluation for Airlines Including the Consideration of Financial Ratios", Journal of Air Transport Management, Cilt 6 133-142, 2000.

24. Wang, Y-J., "Applying FMCDM to Evaluate Financial Performance of Domestic Airlines in Taiwan", Expert Systems with Applications, Cilt 34, 1837-1845, 2008.

25. Tung, C-T., Lee, Y.-J., "The Innovative Performance Evaluation Model of Grey Factor Analysis: A Case Study of Listed Biotechnology
Corporations in Taiwan”, Expert Systems with Applications, Cilt 37, 7844-7851, 2010.

26. Lee, P., T-W., Lin, $C-W$. , Shin, S-H., "A Comparative Study on Financial Positions of Shipping Companies in Taiwan and Korea using Entropy and Grey Relation Analysis",Expert Systems with Applications, Cilt 39, 5649-5657, 2012.

27. Kung, C-Y., Wen, K-L., “Applying Grey Relational Analysis and Grey Decision-Making to Evaluate the Relationship Between Company Attributes and its Financial Performance-A Case Study of Venture Capital Enterprises in Taiwan", Decision Support Systems, Cilt 43,842-852, 2007.

28. Huang,C-J., Kuo-Chung, M.A., "Associating Grey Relation and Cluster Analysis to Perform Financial Characteristic Study on Enterprises in China", Journal of Information \& Optimization Sciences, Cilt 32, No. 4, 945-957, 2011.

29. Brauers W.K.M., Zavadskas, E. K., Turskis, Z., Vilutiene, T., "Multi-Objective Contractor's Ranking by Applying the MOORA Method", Journal of Business Economics and Management, Cilt 9, No. 4, 245-255, 2008.

30. Chakraborty, S., "Applications of the MOORA MethodforDecisionMaking in Manufacturing Environment", International Journal of Advanced ManufacturingTechnology, Cilt 54, 1155-1166, 2011.

31. Karande, P., Chakraborty, S., "Application of Multi-Objective Optimization on the Basis of Ratio Analysis (MOORA) Method for Materials Selection", Materials and Design, Cilt 37, 317324, 2012.

32. İç, Y.T., Yıldırım, S., "MOORA-Based Taguchi Optimisation for Improving Product or Process Quality”, International Journal of Production Research, Cilt 51, No. 11, 3321-3341, 2013.

33. İnternet: Kamuyu Aydinlatma Platformu, KAP, www.kap.gov.tr.

34. Parkan, C., Wu, M-L., "Decision Making and Performance Measurement Models with Applications to Robot Selection", Computers and Industrial Engineering, Cilt 36, 503-523, 1999.

35. Opricovic, S., Tzeng, G.H., "Compromise Solution by MCDM Methods: A Comparative Analysis of VIKOR and TOPSIS", European Journal of Operational Research, Cilt 156, 445-455, 2004

36. Deng, J., "Control problems of grey system", Systems \& Control Letters, Cilt 1, 288-294, 1982.

37. İç, Y.T., Yıldırım, S., Çok Kriterli Karar Verme Yöntemleriyle Birlikte Taguchi Yöntemini Kullanarak Bir Ürünün Tasariminin Geliştirilmesi”, Journal of The Faculty of Engineering and Architecture of Gazi University, Cilt 27, No 2, 447-458, 2012. 
